\title{
Nation-Building, Industrialisation, and Spectacle: Political Functions of Gujarat's Narmada Pipeline Project
}

\author{
Mona Luxion \\ School of Urban Planning, McGill University, Montréal, Québec, Canada; m.luxion@gmail.com
}

ABSTRACT: Since 2000 the Indian state of Gujarat has been working to construct a state-wide water grid to connect $75 \%$ of its approximately 60 million urban and rural residents to drinking water sourced from the controversial Sardar Sarovar Dam on the Narmada River. This project represents a massive undertaking - it is billed as the largest drinking water project in the world - and is part of a broader predilection toward large, concrete-heavy supply-side solutions to water insecurity across present-day India. This paper tracks the claims and narratives used to promote the project, the political context in which it has emerged, the purposes it serves and, following Ferguson (1990), the functioning of the discursive-bureaucratic 'machine' of which it is a product. The dam's reinvention as the solution to Gujarat's drinking water shortfall - increasingly for cities and Special Industrial Regions - reflects a concern with attracting and retaining foreign investment through the creation of socalled 'world-class' infrastructure. At the same time, this reinvention has contributed to a project of nationbuilding, while remaining cloaked in a discourse of technological neutrality. The heavy infrastructure renders visible Gujarat's commitment to 'development' even when that promise has yet to be realised for many, while the promise of Narmada water gives Gujarat's leaders political capital with favoured investors and political supporters. In conclusion, I suggest that the success of infrastructure mega-projects as a political tool is not intrinsically tied to their ability to achieve their technical and social objectives. Instead, the 'spectacle' of ambitious infrastructural development projects may well yield political gains that outweigh, for a time, the realworld costs of their inequity and unsustainability.

KEYWORDS: Development, Sardar Sarovar Dam, Narmada pipeline project, anti-politics, Gujarat

\section{INTRODUCTION}

In 2000, the Government of Gujarat (GoG) set out to construct a state-wide water grid to connect $75 \%$ of the state's approximately 60 million urban and rural residents to drinking water sourced from the Sardar Sarovar Dam on the Narmada River (SSNNL, n.d.). This has been the Government of Gujarat's primary response to the issue of water scarcity for domestic and industrial use, replacing local dam- and groundwater-based schemes across the state (Hirway and Goswami, 2008; GIDB 2009; interview with Nafisa Barot, 14 May 2013). Known as the Sardar Sarovar Canal Based Drinking Water Supply Project, or more colloquially as the Narmada Pipeline Project, the water grid represents a massive undertaking in its own right - it is billed as the largest drinking water project in the world - and is an expansion of the original plan for the controversial Sardar Sarovar Dam, which primarily serves irrigation and hydroelectric purposes (Fisher, 1995; Vyas, 2001; Aandahl, 2010; SSNNL, n.d.). It comes at a time when large infrastructure solutions to water shortages seem to be gaining renewed attention across India including revived discussion of a nation-wide river-linking scheme (Bagla, 2014) - and has led to copycat projects in Telangana and Maharashtra (The Hindu, 2015; Vyas, 2016).

While the Sardar Sarovar Dam is sometimes called the most studied dam in the world (Patel, 1995), the majority of that research has focused on justifying the dam (Pathak, 1991; Narayan, 2001; Vyas, 2001), the upstream human and environmental impacts of the dam (Baviskar, 1999; Morse and Berger, 
1992), the flawed resettlement process (Kothari, 1996; Drèze, et al., 1997; Dwivedi, 1999; D'Souza, 2002), and the anti-dam movement and legal battle surrounding its construction (Fisher, 1995; Jain, 2001; Dwivedi, 2006; Cullet, 2007; Parasuraman, et al., 2010). Aandahl (2010) has looked at the justification, design, and implementation of the irrigation component, while Mehta $(2001,2005)$ looks at the discourses of scarcity used to justify the dam.

This paper - part of a larger research project on low-income people's access to water in urban Gujarat - looks at the way the Narmada Pipeline Project has been presented by state officials and discussed in media coverage to understand the way that it functions discursively and politically. The drinking water component of the Sardar Sarovar Project (SSP) has been understudied so far, and presents some interesting features due to being a type of heavy infrastructure that is rarely seen on this scale, and coinciding with governance reforms in Gujarat at the turn of the millennium. Situating the conception and construction of the drinking water grid within a context of economic liberalisation, governance reform, and state-level nation-building, I examine what the concepts of the developmental state (Johnson, 1982) and the anti-politics machine (Ferguson, 1990) can contribute to understanding the recurring appeal of such concrete-heavy, supply-side responses to drinking water scarcity.

In order to fulfil these objectives, I read Government of Gujarat (GoG) publications on water policy and the pipeline project, scholarly publications by state officials involved in the project, and Englishlanguage local newspaper coverage of the project between 2000 and 2015. Interviews with six civil society observers (academics and activists) and three state bureaucrats also helped guide my thinking. Unfortunately, due perhaps to the controversies which have dogged the SSP since its inception, the few state bureaucrats who did agree to meet me were reluctant to discuss decision-making processes or share master planning documents, leaving me reliant on secondary sources to understand the ways the project has evolved over time and the motivations for various decisions. In that regard academic publications by (former) state officials, as well as Aandahl's (2010) extensive interviews with decisionmakers involved in earlier master-planning processes, proved very useful.

The Government of Gujarat publications consulted include Gujarat Jal-Disha 2010 (GSDWICL), Blueprint for Infrastructure Gujarat 2020 (GIDB), Building Partnerships and Working Together (WASMO), as well as the contents of the websites of the Gujarat Infrastructure Development Board (GIDB), Gujarat Water Infrastructure Limited (GWIL), Gujarat Water Service and Sanitation Board (GWSSB), Sardar Sarovar Narmada Nigam Ltd. (SSNNL), and Water and Sanitation Management Organisation (WASMO). Academic publications by government officials include articles by Andrea Biswas-Tortajada (WASMO), Jay Narayan Vyas (Minister for Narmada and Major Irrigation Projects), and Rajiv K Gupta (SSNNL). Finally, I conducted a search of the online archives of Ahmedabad editions of the Times of India, Economic Times, DNA India, and the Indian Express for articles containing the terms Narmada or Sardar Sarovar between January 1st, 2000 and December 31st, 2015.

\section{HISTORY AND CONTEXT}

Before we look at the Narmada pipeline project itself, some historical background will prove useful. Located along the coast and adjacent to modern-day Pakistan, the area of present-day Gujarat has a long tradition of trade and migration and has long had not only Hindu, Muslim and Jain communities but also Jewish and Parsi (Zoroastrian) ones (Ibrahim, 2007). Over time, different regions have come under the rule of various local rulers or invading forces, creating a complex historical/cultural patchwork of political power. After the British East India Company conquered the Maratha empire in the early 19th century, the region was broken down into a mix of princely states and areas under the direct administration of the British Bombay Presidency, most of which were merged into Bombay State at India's independence. 


\section{Independence and the creation of Gujarat}

Post-independence, the rise of movements for ethno-linguistically defined states highlighted tensions between Marathi-speakers in the southern part of Bombay State and Gujarati-speakers in the north (Yagnik and Sheth, 2005). The Mahagujarat (literally, great Gujarat) movement for the creation of a Gujarati state grew throughout the 1950s, culminating with the separation of Bombay State into Gujarat and Maharashtra in 1960. An important part of the Mahagujarat movement was the construction, at least on paper, of a unified Gujarat out of four distinct regions which have little historical or cultural basis of unity (Simpson and Kapadia, 2010). This construction was largely an endeavour of middle- and upper-class Hindus and Jains in the south/central cities of Ahmedabad, Vadodara (Baroda), and Surat, whose strong labour unions were the backbone of the movement, and the image of essential Gujarati identity that they fashioned was unsurprisingly in their image (Bobbio, 2012; Simpson, 2013). The placement of the state's new capital, Gandhinagar, has only reinforced the role of south Gujarat as the state's cultural and political heartland.

The south/central region contains the state's three largest cities and the areas of greatest average rainfall. In contrast, the regions of Saurashtra and Kutch are both geographically and culturally quite distinct from central Gujarat (Mehta, 1997; Hirway, 2000; Joshi, 2000; Ibrahim, 2007). Saurashtra is a coastal peninsula, largely divided from the mainland by the Gulf of Khambat and the Little Rann of Kutch. Kutch is even more isolated: between the Gulf of Kutch to the south, the Ranns (salt-marshes) to the east and the Thar Desert to the north, Kutch was functionally an island until a rail link was established in the early 20th century (Ibrahim, 2007). Kutch and Saurashtra were each independent kingdoms which remained separate polities under the British Raj and even after Independence, and were only combined with Bombay State in 1956. In addition to representing culturally distinct groups from central Gujarat, Kutch and Saurashtra are border/coastal areas and are home to a higher percentage of Muslims than other parts of the state. In light of contemporary geopolitics and the sectarian nature of local politics, development in these regions is presented as part of a counter-terror effort, and their integration into the ambit of central Gujarat as a necessary counterweight to the perceived influence of Pakistan. Kutch, in particular, has long been portrayed in the popular imagination of non-Kutchis as a wild and potentially dangerous place, whether due to its land border with and cultural affinities to Pakistani Sindh, or to its harsh and 'lawless' desert (Ibrahim, 2007; Simpson, 2013).

Since 1960, Gujarat has also seen growing sectarian tension that has periodically escalated into violence, including most recently the Rashtriya Swayamsevak Sangh (RSS)-led anti-Muslim pogroms of 2002. Infrastructure has served an important role in the construction of dominant Gujarati identity: Mehta (2010) describes how over the 1980s and 1990s an NGO-led movement in support of the Sardar Sarovar Dam engaged Hindu traditions such as garbas to create an emotive connection to the dam and a sense of entitlement to Narmada water. She writes (Mehta, 2010: 514):

support for the dam became the litmus test for 'loyalty' to Gujarat and opposition to it, the ultimate act of disloyalty. [The movement's] tropes of collective pride and suffering built on earlier ideas of regional consciousness, such as K.M. Munshi's concept of Gujarati asmita or pride while also going beyond them to specify a distinct vision of the ideal Gujarati polity.

Looking at the early 2000s, Simpson (2013) describes how post-earthquake reconstruction efforts offered an opportunity for Hindu charities to adopt affected villages and reconstruct them according to their Hindu nationalist beliefs. At the same time, water scarcity in Saurashtra and especially in Kutch has been a major argument in favour of the Sardar Sarovar Project as a whole and the drinking water pipeline in particular (Mehta, 2005; Aandahl, 2010); we will see below how the Narmada pipeline project helps to assimilate minority regions into a political and economic agenda largely dominated by Hindu central/south Gujarati interests. 


\section{Industrialisation and the developmental state}

Sinha (2003) notes that although state intervention in the economy at India's national level is generally regarded as a failure, Gujarat has long exhibited classic characteristics of a developmental state defined by state direction of a capitalist economy, typically through investment, coordination with the private sector, and targeted incentives. Johnson (1999: 38) identifies four features of the developmental state:

1. an elite bureaucracy whose duties are to identify industries to be developed and strategies to develop them, and to monitor competition in these sectors to promote their health and success;

2. "a political system in which the bureaucracy is given sufficient scope to take initiative and operate effectively. This means ... that the legislative and judicial branches of government must be restricted to 'safety valve' functions";

3. "market-conforming forms of state intervention in the economy" including tax incentives, venues for discussion and coordination between business leaders and bureaucrats, and "extensive reliance on public corporations, particularly the mixed public-private variety"; and

4. a vertically-integrated and relatively independent organisation to serve as a hub for industrial policy, such as Japan's MITI (Ministry of Trade and Industry).

Sinha highlights that even when public-sector development was at its peak across India, Gujarat's economy was weighted much more heavily toward the private sector and especially the joint (publicprivate) sector than that of other Indian states with similar histories. In fact, Gujarat's political and bureaucratic elites actively worked to attract private-sector investment even under the central government's system of tightly controlled business licenses. Sinha (2003: 471) writes:

Gujarat (...) designed institutional mechanisms to collect industrial information and then disseminated it to industrial entrepreneurs. In its effort to ensure investment flow from Bombay, Calcutta, and East Africa in the 1960s and 1970s, it generated databases of the potential entrepreneurs and [created] a specialised body, iNDEXTb (Industrial Extension Bureau), to collect data and information. [I]n an explicit effort to develop sectoral leadership (...) in chemicals in the 1960s and in electronics in the 1990s, iNDEXTb and other industrial agencies collected industry-related information about many sectors.

Even before India's national programme of economic liberalisation increased the freedom of individual states to direct their own economies, the GoG was evidencing key aspects of a developmental state. The former head of the state corporation in charge of the Sardar Sarovar Dam (Gupta, 2001: 57) expresses the prevailing vision of the state's role as follows:

The (...) planner [should adopt] as his/her broad objective the formulation of projects and programmes that provide for development and use of (...) resources (...) which will contribute to maximisation of national welfare. The fundamental basis for choice between the alternative courses of action must be economic efficiency.

In the 1990s, in the wake of India's balance of payments crises, the central government dramatically liberalised its economic policies. In Gujarat, where the industrial collapse of the 1980s had gutted the state's cotton mills, the New Industrial Policy was adopted with gusto by the newly elected Bharatiya Janata Party (BJP), and began to take on its own ethno-nationalist flavour (Hirway, 2000; Bobbio, 2012). Bobbio (2012) describes how ideas that were spreading nationally and internationally, such as the promise of 'trickle down' economic growth and the image of modernity as technological progress, were combined in Gujarat with a narrative of Gujaratis as an industrious and business-savvy community, uniquely suited to modernity and development. At the same time, the Asian Development Bank (ADB) chose Gujarat as a test case for state-level loans and structural adjustment programs, noting the "reform orientation" of the state's leadership (ADB, 2004). These reforms aimed at "supporting the GoG 
in augmenting domestic resource mobilisation, improving the allocation and efficiency of the public sector, and reducing GoG's role in commercial activities while promoting market-oriented policies to enhance private-sector participation in infrastructure development" (ADB, 2004: 8). Among other projects, this included developing the Gujarat Infrastructure Development Board (GIDB), which promotes public-private partnerships and 'bankable' projects that will pay for themselves through debt financing and user fees. The GIDB works closely with iNDEXTb to develop an integrated infrastructure/industrial policy - including through the development of Special Industrial Regions (SIRs) - and places officials in other branches of the bureaucracy in order to assure its functioning as an integrated whole with a united vision (interview with GIDB official, 7 August 2013). Overall, postliberalisation reforms have increased Gujarat's ability to function as a cohesive developmental state.

\section{Gujarat in the new millennium}

The early 2000s continued to be a tumultuous time for the state of Gujarat. Following lower-thanaverage rainfall in the 1999 monsoon, summer 2000 was marked by a profound drought that led to riots and a political crisis as the state government maintained their ignorance of the issue until it was far too late (SANDRP, 2000). ${ }^{1}$ It is notable that severe droughts in the 1980 s were instrumental in making the argument for the Sardar Sarovar Dam as a whole (Wood, 1993; Cullet, 2007). In January 2001, a fierce earthquake struck Kutch, killing tens of thousands of people and leaving the district's infrastructure and housing stock devastated. The earthquake and the reconstruction efforts that followed had a dramatic impact on the state, not least of which was the appointment of BJP strategist Narendra Modi in October 2001 to replace the then-Chief Minister Keshubhai Patel, whose alleged poor management of the disaster cost him his position in the party leadership (Jaffrelot, 2008; Pathak, 2001). Mr. Modi's charisma, political acumen, and mobilisation skills honed as an organiser (for the RSS) won him re-election to the position three times, and he served as Chief Minister until his election as Prime Minister of India in 2014. ${ }^{2}$

Mr. Modi's first election in 2002 was won on a platform conflating Gujarati and Hindu identities (Jaffrelot, 2008; Bobbio, 2012), but the sectarian politics that had allowed the BJP to consolidate its position locally did not go over so well nationally and internationally. In 2003, the creation of the Vibrant Gujarat investors' summit - organised biennially by iNDEXTb to bring together industry, government, and outside investors - marked a deliberate shift in political discourse towards a focus on economic development and 'good governance'. Bobbio (2012: 667) writes, "Modi projected himself as a model of the Gujarati ethos, making business a pivotal element of his political image. In doing so, he projected himself as a leader with strong roots in the local community and culture, but at the same time strongly committed to leading the state's economy in the global market". At the same time as the BJP sold strong local support to foreign investors as a sign of the state's stability and businessfriendliness, they presented Mr. Modi's support among international investors as an example of his strength as an advocate for Gujarat and Gujaratis (Ibrahim, 2007; Bobbio, 2012). More recently, Gujarat's GDP growth has been promoted in India and abroad as an anti-poverty success story, and the governance model adopted by the state government in recent years has been widely promoted as the

\footnotetext{
${ }^{1}$ Gujarat's year consists of three seasons: a dry winter, followed by temperatures up to $50{ }^{\circ} \mathrm{C}$ in the summer months of April, May, and early June. The period from late June to early October provides the entirety of the year's rainfall, which must be carefully stewarded to avoid shortfalls in the hottest part of the following year. Although the 2000 drought was immediately precipitated by a weak monsoon, the extent of the drought - in which water reserves were reportedly at a 100-year low - was much worse than a single bad year could account for and revealed the extent to which local groundwater had been overexploited and dam maintenance neglected (SANDRP, 2000).

${ }^{2}$ The Rashtriya Swayamsevak Sangh (RSS) is a Hindu nationalist volunteer service and paramilitary organisation. The RSS is surrounded by a family of sister organisations known as the Sangh Parivar, of which the ruling Bharatiya Janata Party (BJP) was established as the political wing.
} 
'Gujarat model of development' (Dholakia and Dholakia, 2015; The Economist, 2015). Regardless of the Gujarat Model's much-debated economic soundness, it has undeniably been politically successful: not only was Mr. Modi the longest-standing Chief Minister in Gujarat's history, but the BJP swept the 2014 federal elections largely on the strength of his commitment to bringing Gujarat's development to the rest of the country (Jaffrelot, 2015b).

The Economist's (2015) succinct primer on Gujarat's economy states that an "emphasis on basic infrastructure [is] a hallmark of the Gujarat Model". Large-scale physical infrastructure such as improved highways is considered essential to facilitating economic growth (especially in the form of outside investment in industry) while also serving as visible symbols of the state's modernity and 'world-class' status (GIDB, 2009; Desai and Roy, 2016). Quoting an analyst with the IDFC Institute, Mumbai, The Economist (2015) writes: "Mr. Modi's biggest feats were tangible ... the kind of improvements that migrant workers tend to notice, and report back to their relatives". Proponents of the model tend to employ outward-looking rhetoric that situates Gujarat in an international space and contrasts the state with the 'backward' rest of the country (Dholakia and Dholakia, 2015), and aspirational Government of Gujarat documents are peppered with examples from successful developmental states such as Singapore and Korea (GIDB, 2009). This approach to infrastructure is encapsulated here by the GIDB (2009):

Gujarat stands far ahead of other states of India in the availability of quality physical, industrial and social Infrastructure [sic]. Gujarat's achievements and the entrepreneurial spirit of Gujaratis enable them to think bigger and aim higher. There is a conviction that Gujarat should be benchmarking itself to the developed countries of the world and is working towards GDP growth in excess of 11 percent [per year] in the coming years to bridge the gap.

Water pipelines fit neatly into this vision, allowing the government to ensure ample water for industry and the amenities of 'world-class' life, while serving as a visible embodiment of state power in the service of development.

The Gujarat Model is also strongly associated with Narendra Modi's political leadership. As Chief Minister, Mr. Modi's image - typically in Hindu orange - was omnipresent on billboards and newspaper covers, cultivating a sense that "Modi is Gujarat and Gujarat is Modi" (Jaffrelot, 2015a: 14). The branding has been extremely effective even among those who have been neglected by his development agenda: one woman I interviewed who was suffering from a lack of water in her slum told me that "Narendra Modi is a good person" even as she added, "but he doesn't care about poor people". Desai and Roy (2016) describe the prevalence of similarly ambivalent endorsements among working-class and lower-middle-class Gujaratis who are drawn to the BJP and Mr. Modi by communal identity and aspirational class values, despite sometimes contradictory material interests.

Within the government and his party, Mr. Modi is known for centralising power: preferring to work only with people whose loyalty he is certain of and ostracising those who threaten his vision (Verniers, 2015). He has been referred to as a 'one-man cabinet'; as Chief Minister he allocated himself up to 14 ministerial portfolios, including the Narmada and Kalpasar projects as well as the Industries, Ports, Home, and Information ministries, among others (Express News Service, 2012; Patel, 2013). The tendency toward the centralisation of power - and its investiture in a single charismatic figure - are notable, not the least for the impact they have had on infrastructure and policy design. At the same time, Mr. Modi's rise has benefited the BJP as a party and the coalition of interests they represent at both a state and at a national level, and his governance style must be understood as a strategy of the modern BJP rather than the actions of an individual.

\section{Water policy}

Despite reports of a forthcoming state water policy in 2012 - intended to follow the 10-year revision of the national water policy first adopted in 2002 - the state of Gujarat still does not have a 
comprehensive water policy (Jha, 2013; Dave, 2016). The Gujarat Water Supply and Sewerage Board (GWSSB) is by law responsible for state-wide planning to provide drinking water and sanitation, determining the pricing of drinking water and recovering those charges, as well as ensuring (through contracts) the construction, operation and maintenance (O\&M) of certain rural drinking water supply schemes. Meanwhile, the Narmada, Water Resources, Water Supply, and Kalpasar Department, headed by four cabinet ministers, governs irrigation. While GIDB works with these and other departments to coordinate and facilitate infrastructure development, there is no similar coordinating body to monitor and equitably distribute the state's existing water resources. The Gujarat Water Regulatory Authority (GWRA), formed in 2012 in anticipation of the state water policy, was defunct within a year (Dave, 2013).

My interviewees pointed to the influx of post-earthquake development aid beginning in 2001 as a watershed moment for the adoption of development discourse and practices from international NGOs and donors, including the restructuring of the water sector with the aid of the Dutch government in 2002 that created Gujarat Water Infrastructure Ltd. (GWIL) to construct and operate the Narmada canals and pipelines, as well as the Water and Sanitation Management Organisation (WASMO), a GoG special purpose vehicle and registered charity. While the WASMO website describes it as reflecting "a shift from the supply-driven government-owned systems to decentralised demand-driven, communityowned water supply systems" (WASMO, 2016), the organisation's 2015 promotional brochure acknowledges that the organisation was formed to "augment" the pipeline grid by "creat[ing] the infrastructure requisite for taking drinking water up to individual villages or village clusters ... Then, the responsibility of maintaining, strengthening and sustaining that last-mile infrastructure is handed over to the respective communities" (WASMO, 2015: 4-5). Local pani samitis (water committees, an unelected 'participatory' body) are charged with operating and maintaining the infrastructure and collecting water charges to pay for the Narmada water they are issued. This 'demand-driven' (though not demand management) approach is therefore better understood as an extension of centralised supply megaprojects than an alternative to them.

Across the board, the GoG's approach to water shortages has primarily focused on increasing supply: GIDB (2009: 25) writes, "Gujarat has significantly addressed its water problems by using the strategies of rainwater harvesting, check dams and interbasin transfers". Initiatives to make water use more sustainable have typically focused more on reducing waste and runoff - particularly through rainwater capture for groundwater recharge - than on demand management (GSDWICL, 2010; WASMO, 2016). Nonetheless, occasional attempts at demand management can be seen. In 2007 and 2011, the price of bulk water to industry was raised from Rs. 10 to Rs. 15 and then to Rs. 30 per kilolitre (USD $0.25,0.38$, and 0.67 , respectively) to respond to higher demand and delivery costs, although the price was deliberately kept low enough to be competitive those of with other states (Shah, 2010). While the possibility of making household water meters compulsory is raised periodically, so far the cost and technical challenges of measuring irregular flow have been prohibitive and households are typically charged a municipal water tax that does not reflect actual consumption. In rural areas, however, the Jyotigram Yojana electrification scheme has begun rationing electricity to farms in order to reduce the exploitation of groundwater with electric motors (Shah et al., 2008).

As a result of these fragmented governance structures and the ambitious scope and centralisation of the Narmada Pipeline Project, since the advent of the project it has essentially dominated drinking water and industrial water policy in Gujarat. The following section looks at the Narmada Pipeline project itself, beginning with the decades-long political struggle over the Sardar Sarovar Dam that has been an integral part of contemporary Gujarati politics. 


\section{The Narmada Pipeline Project}

\section{The Sardar Sarovar Dam}

While the focus of this paper is on the Narmada Pipeline Project, this project cannot be fully understood without some background on the history of the Sardar Sarovar Dam and its role in Gujarat's political economy. The state of Gujarat is semiarid to arid, with few year-round surface water sources of which the Narmada River, which passes through the south of the state, is one of the largest - and rainfall patterns which favour the subtropical south/central areas of the state over north and west. The region has traditionally relied on wells, monsoon-fed tanks and ponds, and seasonal rivers for its water needs (Hardiman, 1998). Reliance on human- or ox-power to dig and draw water from wells effectively limited groundwater exploitation to amounts that could be replenished seasonally through natural processes. In the more water-scarce areas, pastoral lifestyles and practices of rain-fed agriculture also limited water use (Mehta, 2001, 2005). As rural Gujarat was electrified in the 1980s and 1990s at advantageous rates for farmers, groundwater exploitation skyrocketed, leading to extremely depleted levels across many parts of the state (Mukherji, 2006). While a policy was introduced in the mid-2000s to ration electricity to farmers in order to reduce groundwater exploitation (Shah et al., 2008), reliance on fluoride and arsenic contaminated aquifers, salinity ingress, and simple lack of water are real and growing issues for many of the state's residents (Hirway, 2005). At the same time Mehta (2005) underscores that assertions of water scarcity have become a normalised and unquestioned part of Gujarat's political discourse, and notes that evaluations of scarcity rely on culturally bound assumptions about 'normal' water use patterns that erase traditional lifestyles.

Discussions on capturing the waters of the Narmada river for 'productive' use date back to the British colonial period, although concrete planning for dams began around 1960 (Ferguson and Sinnott, 1969; Drèze et al., 1997). The SSP is neither the first nor the largest dam to be built in postIndependence India, but it became perhaps the most controversial as campaigns to stop the eviction of farmers and Adivasis $^{3}$ from the Narmada valley transformed into a movement with international resonance opposing large dams in general and the entire model of development they were seen to stand for (D'Souza, 2002; Shiva, 2002; Dwivedi, 2006; NAPM, 2010). Locally, the movement highlighted major oversights in terms of environmental impact assessment and the implementation and design of resettlement policies, contributing to the World Bank's decision to order an independent inquiry into the project in 1992 which came back deeply critical of the project (Morse and Berger, 1992). Seeing the writing on the wall, the Government of India chose to pre-emptively refuse the remainder of the Bank loan instead of seeing the funding pulled, while the Government of Gujarat published a vehement rebuttal titled No Cancelling Tomorrow. Active opposition to the dam continues to this day, although in a weakened form, and the fate of many displaced people remains far from clear (NAPM, 2010). Meanwhile, within Gujarat the prominent attitude has been that 'there is no alternative' (Vyas, 2001) to a supply-side approach to Gujarat's water woes, and that the SSP is the natural solution (Pathak, 1991; Gupta, 2001; Narayan, 2001; Cullet, 2007). As we have seen, even mild opposition to the dam is portrayed as anti-Gujarati (Mehta, 2010), and NBA movement leader Medha Patkar has been regularly vilified in the press and even accused of being a foreign agent (The Indian Express, 2014).

As the Narmada River traverses several states, the design and construction of the dam involved authorities at all levels of government. Allocation of Narmada River water between the co-riparian states was decided by the federal Narmada Water Disputes Tribunal in 1979, which established the Narmada Control Authority (NCA) to implement the tribunal's decision and oversee conflicts in the ongoing development of the valley. Although the Sardar Sarovar is intended as a joint project of the

\footnotetext{
${ }^{3}$ Indigenous people, also known in India as 'tribals'.
} 
states of Gujarat, Madhya Pradesh, Maharashtra, and Rajasthan, the dam is located within the state of Gujarat and administered by Sardar Sarovar Narmada Nigam Ltd. (SSNNL), a "Wholly owned Government of Gujarat undertaking" (SSNNL, n.d.). Following public interest litigation brought against the dam's construction, in 1999 the Indian Supreme Court ordered SSNNL to obtain permission from the NCA for the construction of each additional five metre increment of height, to be granted only once the Authority was satisfied that resettlement and environmental remediation works related to the previous increment had been completed. Responsibility for these tasks crossed state borders, leading to tensions particularly between Madhya Pradesh - where most of the tens of thousands of displaced people originated - and Gujarat. Due to an appeal of the decision, it was not until 2001 that construction was able to proceed above 85 metres (see Table 1).

Following these many acrimonious delays, the dam finally began providing hydro-electricity and water in 2002 and was inaugurated at its 'final' height of 121 metres on December 31, 2006. The thenChief Minister Narendra Modi led efforts - alongside the SSNNL - to get approval for the installation of gates that would raise the effective height of the dam to 138.7 metres, arguing the increase was necessary in order to extend the reach of Narmada water to the farthest sections of the planned irrigation canal system. This authorisation was granted in 2014, days after Mr. Modi became Prime Minister of India. One headline announcing the increase read "Narendra Modi gives Gujarat its lifeline: Narmada Dam height to be raised by 17 metres; lakhs [tens of thousands] will lose their homes, activists say" (Mohan and Dave, 2014), an apt summary of the conflict. This section has very quickly surveyed the major features of the Sardar Sarovar Project to highlight the backdrop against which the Narmada Pipeline Project was planned and executed. Curious readers are encouraged to read the excellent collections of essays on the dam project edited by Fisher (1995) and Drèze et al. (1997) as well as recent dissertations by Dwivedi (2006) and Aandahl (2010). The relevant legal documents and reports are collected by Cullet (2007).

\section{The Narmada Pipeline Project}

The Narmada Water Disputes Tribunal (NWDT) decision allocated to Gujarat 32\% of the Narmada River's water, or an estimated nine million acre-feet (MAF) per year (Narmada Water Disputes Tribunal, 1979, reproduced in Cullet, 2007). Although the wording of the tribunal decision deliberately allows for variation in yearly flow, the GoG documents I studied universally presented the figure of 9 million acrefeet (MAF) as a fixed amount. ${ }^{4}$ Initial plans for that water provided solely for the irrigation of 1.8 million hectares through an extensive canal system, but a state-level planning process in 1990 allocated 0.9 MAF (roughly 3000 million litres per day or MLD) for drinking water to water-scarce villages in Kutch, Saurashtra, and northern Gujarat (Aandahl, 2010). The drinking water plan was vastly revised following the drought in the early 2000s in order to fast-track water to drought-prone areas through pipelines integrated into a state-wide grid (see Figure 1). These pipelines are also meant to carry an additional 700 MLD for industrial use, bringing the combined non-agricultural uses up to roughly $13 \%$ of the NWDT award to Gujarat (GIDB, 2009).

When permission was granted to start raising the dam in 2001, Gujarat's political leadership rushed to complete it as soon as possible. Meanwhile, farmers had turned out to be unexpectedly reluctant to part with valuable farmland for the construction of canals and resistant to the expectation that they construct the smaller channels themselves (Aandahl, 2010). Between the unexpected cost and delay of constructing the canals and the politically motivated commitment to prioritising dam construction, in 2002 Gujarat found itself with a seeming abundance of Narmada water before irrigation canals were ready to distribute it. Aandahl (2010: 189) quotes Sanat Mehta, ex-chairman of SSNNL, as follows: "[T]he present Chief Minister [Narendra Modi], when he realised that the canals will not be ready in ...

\footnotetext{
${ }^{4}$ In units more usually used for drinking water, $9 \mathrm{MAF} /$ year is roughly 30,000 million litres per day.
} 
time ... and he want[ed] to create the impression all over the country that waters of Narmada has reached the people ... he converted it into a pipeline scheme [for] drinking water". The influx of international funding after the 2001 earthquake also contributed to the pipeline project taking off in a timely way: in Kutch, funds from an Asian Development Bank reconstruction loan were used to construct part of the pipeline (ADB, 2008).

Table 1. Significant dates in the construction of the Sardar Sarovar Dam.

1948

Mar 1960

1965

Jul 1968

1979-80

Apr 1987

1989

Jun 1992

Mar 1993

Feb 1994

Feb 1999

Mar 2001

May 2002

May 2003

Mar 2004

Mar 2006

Jun 2014
Government of India establishes committee to examine several dam projects for the Narmada.

Bombay State is split into two new states: Gujarat and Maharashtra.

Khosla committee plan for the Narmada endorsed by Gujarat; rejected by Maharashtra and Madhya Pradesh.

Gujarat demands that the inter-state water dispute be resolved by a tribunal.

Final decision of the Narmada Water Disputes Tribunal establishes Narmada Control Authority (NCA)

Construction begins on Sardar Sarovar (SSP).

Protests mount; several groups opposing SSP form Narmada Bachao Andolan (NBA).

Report of the World Bank-ordered Independent Review ('Morse Report').

Government of India cancels World Bank loan.

Gujarat High Court stops work on the dam; NBA lodges petition with Supreme Court.

Supreme court allows construction to 85 metres.

Supreme court rules construction may continue upon NCA approval for every 5 metre increase.

NCA gives approval to build up to 95 metres.

NCA approval to raise height up to 100 metres.

NCA approval to raise height up to 110.64 metres.

NCA approval to raise height to up 121.92 metres.

Approval to install radial gates, raising height to up 138.7 metres.

Sources: Cullet, 2007; NAPM, 2010; Mohan and Dave, 2014.

Today, water flows from the Sardar Sarovar Dam into the Narmada irrigation canal, from which it is pumped into pipelines at several pumping stations across the state, ultimately connecting to existing city and village supply schemes. SSNNL sells Narmada water to Gujarat Water Infrastructure Ltd. (GWIL), which delivers and resells it to municipal governments, village pani samitis, or special industrial regions. Each segment (labelled with a letter on Figure 1) of the pipeline grid represents a separate Build-Operate-Transfer (BOT) contract, and GIDB has actively promoted the water sector as a promising business opportunity for construction companies and investors (Vibrant Gujarat, 2014). 
Figure 1. 2001 plan for the Narmada Pipeline Project (reproduced in Pravah, 2009).

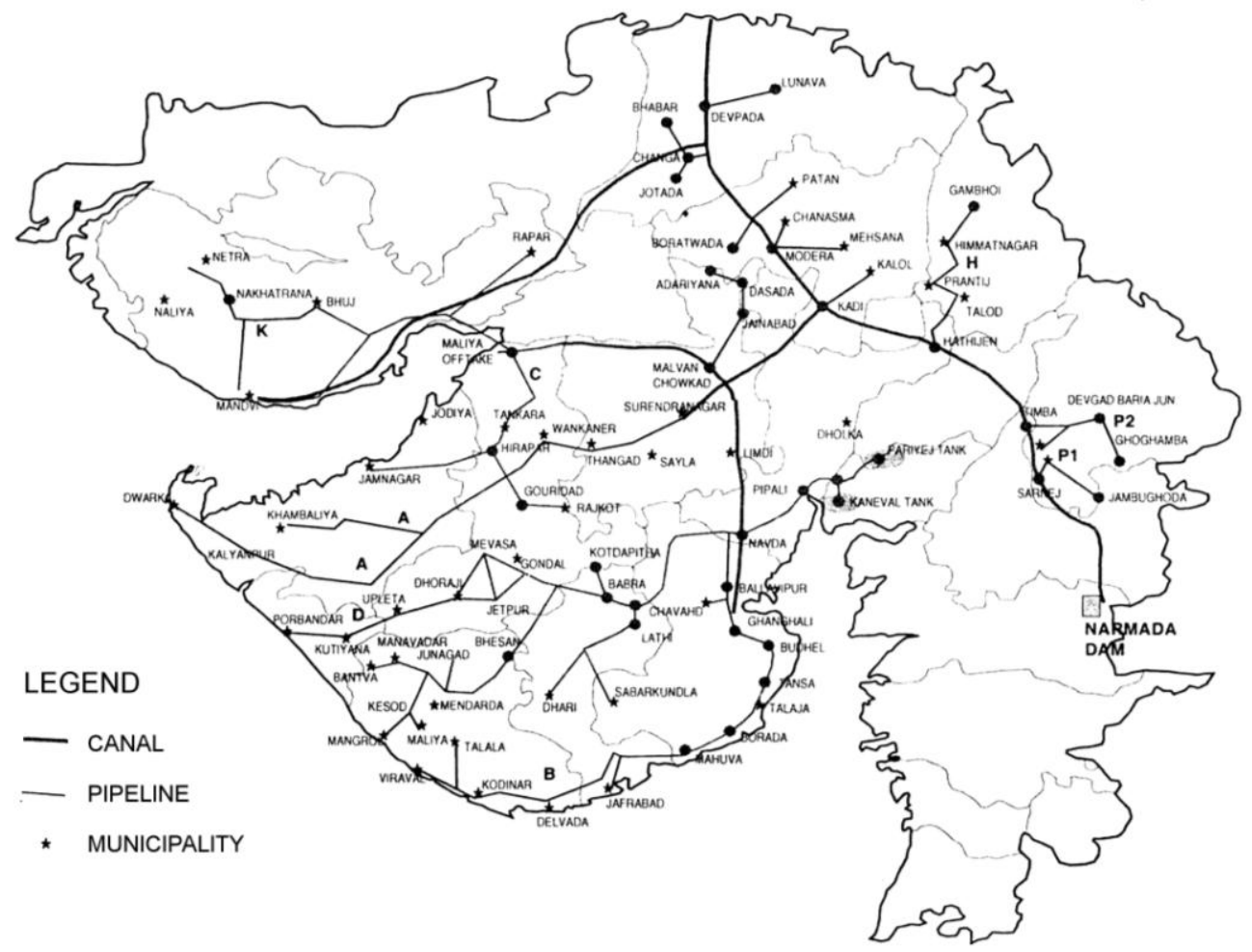

Figure 2. Map of the planned canals, command area, and pipeline grid (SSNNL, n.d.).

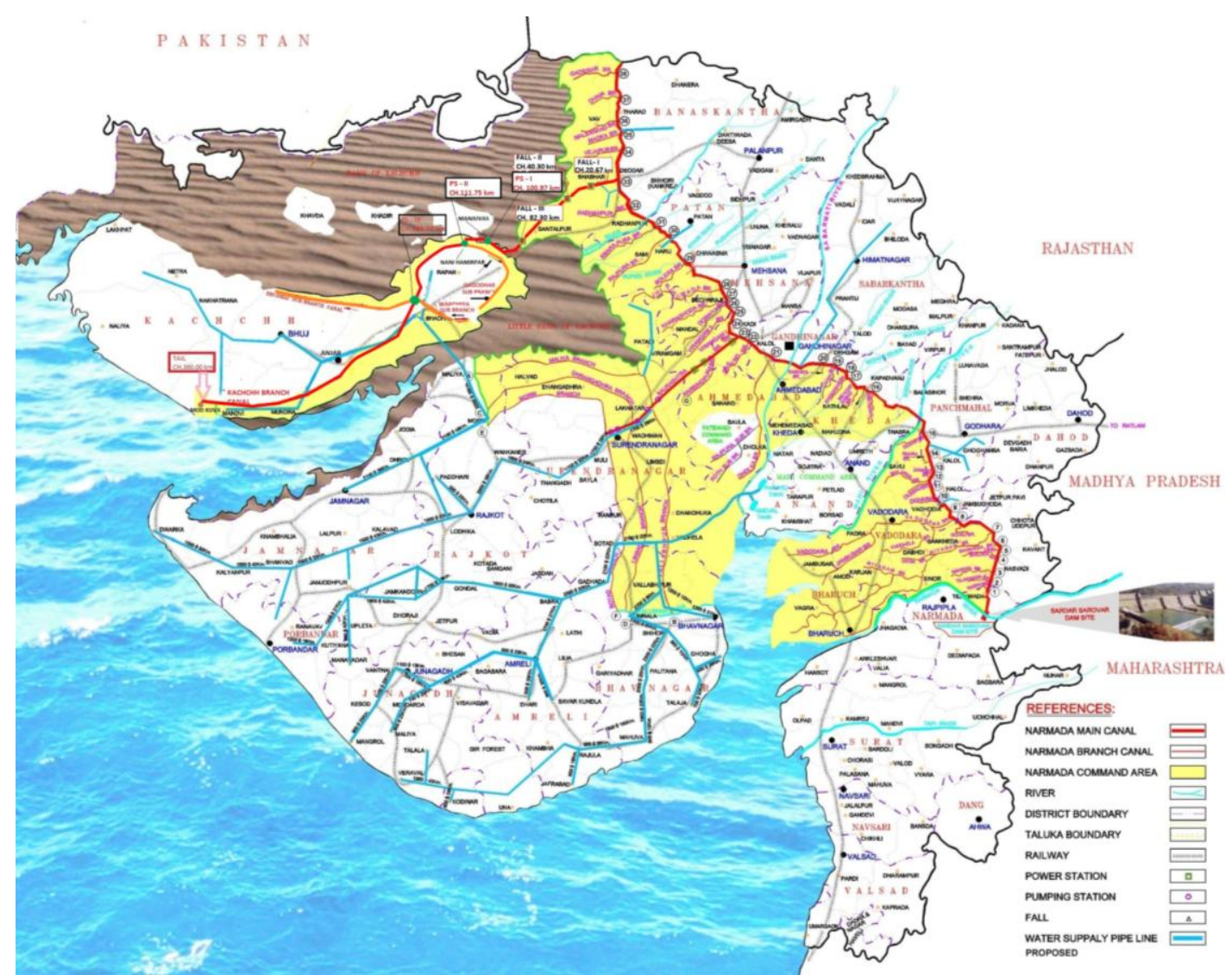


Despite Mr. Mehta's attribution of the drinking water pipeline scheme to Chief Minister Modi, plans for the project had in fact been outlined before Mr. Modi took office (GSDWICL, 2000; Patel, 2001). But Mr. Modi's championship of the project has led it to be associated with his leadership, with several commentators even giving 2002 as the starting date of the project and naming Mr. Modi as its initiator (Biswas-Tortajada, 2014; PTI, 2015a). At a 2015 ceremony inaugurating the pipeline to Saurashtra and Kutch, the then-Chief Minister Anandiben Patel stated: "This is our prime minister's [Narendra Modi's] dream project. He ... had worked tirelessly to solve the water scarcity of this region. He also fought hard to increase the height of Sardar Sarovar Dam and provided us the technology to lay the canals quickly" 5 (Times News Network, 2015a). We can see here the way in which the dam, the pipeline, and modern technology are all rhetorically tied together and linked with an image of Mr. Modi as a benevolent protector for Gujarat.

\section{Implementation and changes to the project}

The initial master plan for the drinking water grid proposed to supply 3500 MLD to 8215 villages and 135 urban areas in Saurashtra, Kutch, north Gujarat and the Panchmahals in the east, costing Rs. 7000 crores or roughly USD1.6 billion (Gujarat State Drinking Water Infrastructure Co. Ltd., 2000). In 2009, the number of villages and towns to be covered remained the same, though mention of the Panchmahals had been dropped as they were now to be covered by a system of check-dams and other existing dams in the centre of the state (Gujarat Infrastructure Development Board, 2009). Today, in 2016, the SSNNL website describes the project as covering 9490 villages and 173 towns, although the amount of water allotted appears to remain the same (SSNNL, n.d.).

In fact, most of the news coverage of the project after the initial announcements addresses demands for, and promises of, Narmada water to new projects and unplanned-for outlays to address crises. First in 2002, and then permanently in 2005, the BJP cabinet allocated Narmada water to 'revive' the Sabarmati River - sacred to Hindus and central to Ahmedabad - which had run dry from overexploitation (TNN 2002, 2005). ${ }^{6}$ This was not the only off-plan use of Narmada water: the 2005-6 report of India's Comptroller and Auditor General highlighted GWIL- and SSNNL-sanctioned "deviation from the master plan" and "excess allocation of water to industrial users" as significantly detracting from Gujarat's ability to effectively deliver on its commitments outlined in the Narmada project master plan, and found a frightening lack of balanced accounting for changing water allocations where increased allocations for industry were not accompanied by corresponding reductions elsewhere (Comptroller and Auditor General of India, 2006: 18-19). This rebuke has not stopped off-plan allocations, however. In terms of drinking/industrial water alone, in 2012-2013, the media archive records permanent allocations of 190 MLD to a special industrial region in the Bharuch-Dahej area near the now-dry mouth of the Narmada (Shah, 2012a), 90 MLD to the Gandhinagar International Tech City Special Economic Zone (John, 2012), and 38 MLD to Vadodara (TNN, 2013). A 2012 plan for publicprivate partnerships (PPPs) to develop water treatment and drainage systems in cities across the state included plans for the provision of 140 litres per capita per day (LPCD) in every municipality by 2014, much of it to be supplied from the Narmada grid. In 2015, new pipeline branches not included in the initial plan were inaugurated to cover yet more area (TNN, 2015a). Aandahl (2010) documents similar concerns with the size of the irrigation command area, which was expanded to include unplanned-for areas in central Gujarat while the farther canals were under construction, only to be confronted with the political impossibility of taking away water entitlements once granted.

\footnotetext{
${ }^{5}$ Although it is unclear what Mrs. Patel meant by this reference to canal-laying technology, the image of the Narmada project as innovative and high-tech is a consistent part of its marketing.

${ }^{6}$ Ahmedabad has since capitalised on the Sabarmati with a riverfront development which displaced hundreds of slum-dwellers (Desai, 2012).
} 
Nonetheless, these allocations are contested by entities both outside and, sometimes, within the state government: city governments and industries demand more water, citing the political and economic consequences of shortages and lobbing accusations of favouritism if other cities or industries are supplied instead of theirs. Meanwhile, farmers facing crop failures protest the allocation of water to urban areas and SIRs instead of agriculture. A 2013 newspaper article even documents a refusal by SSNNL officials of the GIDB's demand for 947 MLD of Narmada water for the Dholera special industrial region (SIR), on the grounds that all 1.02 MAF intended for drinking water or industrial use had already been allocated (Shah, 2013). Although cases that make it into the media are rare, this suggests that intra-government conflict over water allocation is not unheard of. Development of the SIR has moved ahead, with water slated to come from the as yet unbuilt Kalpasar project (Datta, 2015.) While unplanned-for allocations continue, the stated amounts earmarked for drinking water, industry, and agriculture all remain constant (GIDB, 2009; Shah, 2013; SSNNL, 2016).

Meanwhile, there continue to be almost-yearly reports of water crises in Kutch and/or Saurashtra, with tensions rising to the point of full-blown water riots in Rajkot in 2015 (TNN, 2015b). Officials blame theft by farmers along the main canal for the water's failure to reach the pumping station which serves those regions (at Maliya; see Figure 1), repeatedly deploying police to remove illicit pumps as an emergency relief measure and promising to construct more stretches of enclosed pipeline to thwart theft. In 2015, it was reported that the state would begin using unmanned aerial vehicles (UAVs) to monitor the Saurashtra branches of the canal for illicit pumping, and a new State Reserve Police battalion was also announced that year to defend "critical infrastructure" (Parmar, 2015a; PTI, 2015b). However, a 2012 newspaper article on shortages in these areas noted that officials had been lax about enforcing prohibitions on pumping from the canal owing to it being an election year, revealing the perverse incentives dictating how water is controlled in the state (Shah, 2012b). Note that in contrast to the intended downstream beneficiaries, these central Gujarat farmers are located in the cultural heartland of the state and the region with the greatest rainfall and supply of groundwater, and are manifestly financially capable of affording pumps and the electricity to run them. Similarly, most of the one-time emergency relief allocations and all of the permanent unplanned expansions of the water grid identified in the news archive have been to central and south Gujarat.

\section{Effectiveness of the pipeline project}

For decades, the Narmada was heralded as a long-term solution to the issues of drought and thirst in Western India (Ferguson and Sinnott, 1973; Vyas, 2001; Biwas-Tortajada, 2014; PTI, 2015a), and a major claim in favour of the state-wide grid has been that it will assist in creating a "tanker-free" state (TNN, 2015a; WASMO, 2015). ${ }^{7}$ Yet reports on the effectiveness of the project suggest very mixed results. In 2005, a consortium of NGOs working on water-related issues in Gujarat established a citizen monitoring programme in order to understand the effectiveness of the water grid on the ground (Hirway and Goswami, 2008; Pravah, 2009). The study surveyed the 2044 villages covered at the time (roughly $20 \%$ of the entire project), and found that only $82 \%$ of the villages covered officially were actually receiving Narmada water, of which $20 \%$ had received water on fewer than 30 of the past 90 days. Even on days when water was supplied, in the majority of cases it was estimated to be less than necessary to meet the needs of the village. Meanwhile, pani samitis had been constituted in less than $30 \%$ of the villages where water was received, many of which existed only on paper while many more included no women members. As the pani samitis are intended to be responsible for collecting water fees, maintaining intra-village water infrastructure, testing water quality and ensuring representation of women and

\footnotetext{
${ }^{7}$ While tanker trucks are a feature of the waterscape across a wide range of India's regions and socioeconomic classes, their association with drought relief and by extension water insecurity is what lends this image its rhetorical power as a representation of progress and development.
} 
minorities in water governance, this lacuna has profound repercussions for the efficacy and equity of the project. At the same time, shortfalls were found in terms of communication between state-level bureaucrats, contracted valve-men, and village authorities - particularly in terms of water testing and treatment.

More fundamentally, the study found that all of the villages surveyed had existing local sources, either within the village or from small-scale local and regional distribution schemes. While these sources may not have been entirely adequate to serve village needs, since the introduction of the Narmada pipeline the maintenance of these sources had been completely neglected. This caused a reduction in the total amount of drinking water available, and increased villagers' dependence on outside sources over which they have little control, while raising the per-unit cost of water as low-cost sources were replaced with higher-cost Narmada water. This concern was echoed in my own interviews with practitioners in the water sector in 2013.

While an equivalent study has not been done on the urban areas served by the grid, an urban service-level benchmarking project in $2015-6$ found that $80 \%$ of the water provided by municipalities in Gujarat was from surface water sources, and the researchers credit the Narmada Pipeline Project with a reported increase of 50\% over the 2008 level of supply (Performance Assessment Project, 2016). ${ }^{8}$ Even with the project more or less complete, however, the state is struggling to meet the high level of water supply it has promised. While the current reported availability of municipal water supply averages out to roughly 130 LPCD, the minimum level of provision the Government of India mandates for urban areas, the distribution of service is profoundly unequal between cities: Gandhinagar provides a reported 254 LPCD to its residents in contrast to a measly 35 LPCD in Wankaner, Saurashtra. Similarly to the rural findings discussed above, the study reports an average of fewer than two hours of water supply per day, 23 days per month, with no significant improvement over the 2008-2016 study period (Performance Assessment Project, 2016). Given the absence of metering in most urban local bodies most of the data for this study consist of estimates by municipal staff, which suggests that actual numbers may be significantly lower. The data also do not address inequalities within urban areas, nor do they recognise how much of this water is destined for commercial and industrial uses rather than solely for domestic ones.

As a result of the ongoing water shortages, solutions that had been discarded before the Narmada project are now beginning to get more attention. In the short term, these include dam desilting efforts that had previously been deemed overly costly and the use of remote sensing technology to locate sites for new borewells in Saurashtra and Kutch (DNA correspondent, 2013; PTI, 2014). Longer-term, the state is continuing to look to infrastructural megaprojects such as river-linking canals between Gujarat and Maharashtra, and the fantastical Kalpasar Project, a proposed 64-km-long dam across the Gulf of Khambat that would trap the outflow of five seasonal rivers, or essentially the majority of the state's freshwater runoff (GIDB, 2009). In 2012, the construction of "Asia's biggest desalination plant" was announced in Dahej, near the now-dry mouth of the Narmada (TNN, 2012). These projects are being promoted by GIDB as opportunities for public-private partnerships and foreign direct investment (Vibrant Gujarat, 2014). At the same time, at the 2015 inauguration of three new branches of the Narmada pipeline, the then-Chief Minister Anandiben Patel promised that these branches would "permanently solve" water scarcity in Saurashtra and Kutch, proving that the rhetorical power of the Narmada project has not yet run its course (PTI, 2015a).

Overall, the picture painted by the media archive's yearly reports of water shortages and by these two studies is far from the universal, steady 'lifeline' promised by planners and politicians alike, and reveals distribution as unequal and unreliable, affected by political patronage and uneven hydrological

\footnotetext{
${ }^{8}$ Unfortunately, pre-2000 figures are not available, so it is impossible to fully quantify how much of an impact the pipeline project has had on water availability in the state.
} 
cycles as well as by theft, breakage, and over-exploitation. Regardless of the planners' best intentions, the design of the project leaves Kutch and Saurashtra particularly vulnerable to the effects of increased demand in central Gujarat, whether through illicit water pumping by local farmers or more official allocations of water to politically-important locations. This is not to deny the benefits that have accrued, particularly for women, where water has been made available (see, e.g. Mehta, 2011). The apparent discrepancy between promise and reality calls into question the cost-benefit analyses used to justify the project (Pravah, 2009). We might well ask why, then, subsequent generations of politicians are still turning to similar mega-projects for a permanent solution and even continuing to promote and praise the Narmada pipeline project itself? The following sections take us beyond the project's suboptimal performance to describe the political functions it serves and the effects it has had outside of addressing water scarcity.

\section{HYDROCRACY, NATION-BUILDING, AND ANTI-POLITICS}

The majority of existing scholarship on the Narmada pipeline and the larger SSP project has focused either on determining whether it has been successful, or whether it is justifiable. To a great extent, responses to these questions seem predetermined by the authors' political stances, with success and justifiability both measured by moving goalposts, especially as the project continues to expand and change. Regardless of the conclusion, this framing of the question continues to support the idea that the project is a technical solution to a technical problem, and that exposure to the right evidence will therefore generate better water policy in the future.

My experiences discussing the project with project proponents and engineers suggested that there was a different dynamic at play. Although the mid-level bureaucrats I spoke to were adamant that the project was the most efficient way of achieving the desired transfer of water from the Narmada to drought-prone areas, when pressed on the framing of the problem as one of interregion transfer they treated it as self-evident or, at most, as a mandate determined by some unnamed high-level decisionmaker. That the framing of the problem is itself a political choice (Rittel and Webber, 1973) is a point conspicuously absent from these interviews, as well as the news reports and GoG literature I reviewed. Understanding the Narmada pipeline project requires a recognition that it is a product of a larger system of actors and discourses, operating independently yet in tandem (Ferguson, 1990; see also the Deleuzian concept of assemblage, e.g. in Anderson and McFarlane, 2011). This section attempts to describe this network's effects more precisely.

The GoG's discussions of the pipeline project treat it as a technical solution to a technical problem: that of "effective, efficient and sustainable" distribution of water (GIDB, 2009). This is reflected in how the GIDB (2009: 76) presents Gujarat's water situation:

Due to erratic rainfall and ground characteristics, there are regional imbalances in the distribution of water.

(...) While North Gujarat, Saurashtra and Kachchh constitute $71 \%$ of [the] total geographical area of the

State, they account for less than $30 \%$ of the water resources. Further, more than $40 \%$ rainwater flows into

the sea as run off every year due to absence of water conservation structures.

Similar figures about Gujarat's landmass and water resources in relation to India are often used in discussions of the SSP to suggest that the natural distribution of water is unfair and must be rectified (Gupta, 2002; Cullet, 2007). A full accounting of Gujarat's water crises, however, must address the forces that have driven consumption far beyond the capacity of existing natural resources, including the drive toward rapid GDP growth and 'world-class' consumption. Although some acknowledgement of the role played by overconsumption can be found in the state's promotion of drip-irrigation and cuts to agricultural electricity allocations (Shah et al., 2008), the ongoing promotion of highly water-intensive industries such as cement and pharmaceutical manufacturing tell a different story (GIDB, 2009; Sud, 
2009). More fundamentally, state visioning documents regularly prioritise equalising access to resources across the state over adapting land use to local conditions (GSDWICL, 2000; GIDB 2009).

Official documents also do not give any attention to social or political determinants of access to water. Aandahl (2010: 183) writes that the problem of landlessness preventing agricultural workers from reaping the benefits of the SSP was unaddressed by officials she interviewed and that "the existence of poverty in drought-prone regions is seen as a result of lack of water. ... Poverty and unemployment in the [SSP] planners' perspective are only man-made phenomena to the extent that they are due to human neglect of technological options for rectifying nature's distribution of resources". In terms of the drinking water grid, GWIL responsibility extends only to providing a single point source for each local body, from which municipal governments and village pani samiti are responsible for distribution. Issues such as the lack of service in low-income urban areas (Census of India, 2011; unpublished fieldwork) or discrimination within single-source villages are therefore unaccounted for in the plan, a fact brought starkly to light in scattered newspaper reports of Dalit residents being denied access to newly arrived Narmada water (Parmar, 2013, 2015b). By framing the issue simply as a nearly-inevitable regional physical shortage, Gujarat's mega-infrastructural solution to drinking water shortage does little to address the causes of the insecurity experienced by individuals within an unequal society.

\section{The hydropolitics of nation-building}

The role of large waterworks in nation-building has been widely studied in India and elsewhere (Wittfogel, 1957; Swyngedouw, 1999; Klingensmith, 2007; Molle et al., 2009). Swayamprakash (2013: 154) argues that it is the ways of thinking that underlie dam construction and design that are essential to nation-building, more so than any material benefits derived from the final products, as large dams "were meant to fundamentally rearrange natural and social geographies"; the scientific re-imagining of rivers and their surrounding geographies as 'river basins' and catchment areas undercutting the strength of local and regional place-based identities and recasting them as latent resources waiting to be exploited for the good of the nation. In post-Independence India, the displacement of local knowledges set up technical experts as the only legitimate directors of development, creating "powerful state hydraulic bureaucracies [that] became (...) synonymous with the project of 'development'" (Swayamprakash, 2013: 154).

Meehan (2014) characterises water infrastructure as a 'tool' and a 'wellspring' of state power. While Swyngedouw (2009) and other political ecologists make the case for seeing infrastructure as a product of inherently political decisions, Meehan describes infrastructural objects as both 'tools' and 'brokers' of power, not just embodying state power but playing an active role in its reproduction and contestation (see also Bakker, 2010). Thus inherent in any form of infrastructure is the ability to use it in certain ways, and not in others, making technical design decisions far from neutral.

While the drinking water grid physically and administratively unifies large swathes of the state, another project is being simultaneously deployed to politically and affectively unite it - and the country as a whole. The Statue of Unity, portraying Indian independence fighter and statesman Vallabbhai ('Sardar') Patel, is designed to be the world's tallest statue, and will stand at the base of the Sardar Sarovar Dam. The Statue of Unity gains its name from Mr. Patel's role in unifying the country, persuading various jurisdictions to join the newly forming nation. As Mr. Patel was a farmer, farmers across the state and across the country have been solicited to contribute used metal tools and scraps to be melted down into the statue, along with photographs and signatures to be included in the museum at its base.

Given its symbolic link to farmers, situating the statue at the base of the Sardar Sarovar Dam solidly anchors the narrative of the Narmada as a lifeline of rural development, while also placing Narendra Modi's stamp on the project through his strong personal identification with Sardar Patel (Modi, 2012). 
More importantly, the statue and museum will serve to reinforce tourism to the dam site, already served by Gujarat Tourism bus tours and promoted as a picnic area. By linking the dam with a hero, the Narmada project, too, acquires a kind of heroism by proxy. Visits to the museum and statue will reinforce the visibility of the dam to Gujaratis and visitors, helping it serve one of the purposes of megainfrastructure described above: to offer visible evidence of development even to those who have not been directly served by it.

Figure 3. The recreation area at the Sardar Sarovar Dam (source: SSNNL website)

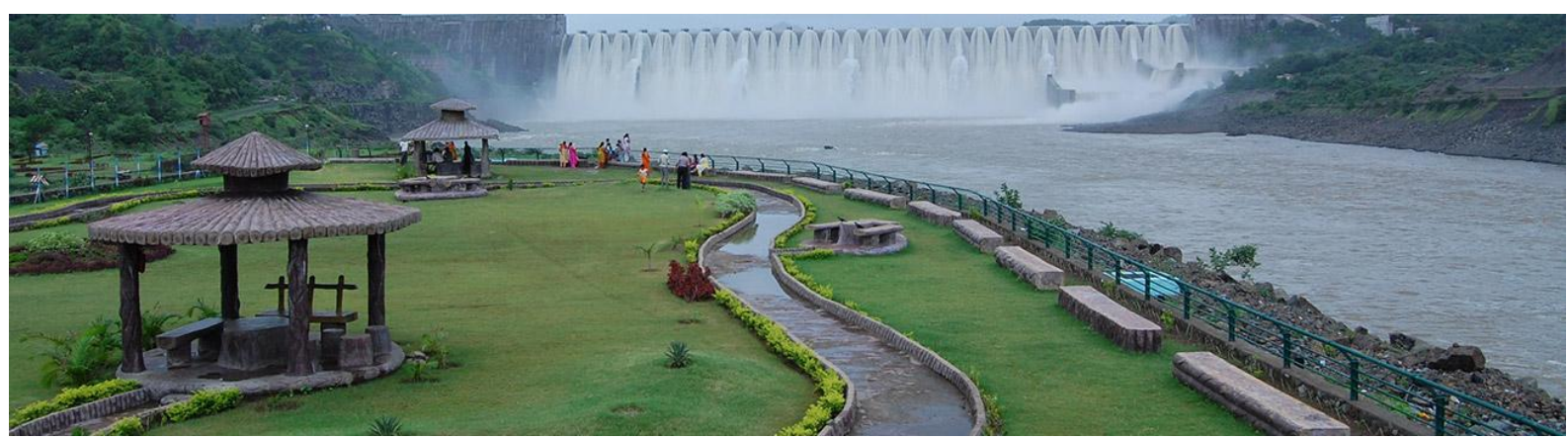

\section{The anti-politics machine}

In his influential study of why development projects in Lesotho have repeatedly failed, Ferguson (1990) describes development actors and discourses as constituting a 'machine' that produces results that go beyond the intentions of any one of its parts. Although the project he studied failed to achieve the stated goal of 'modernising' the region's cattle agriculture, it nonetheless has a range of predictable and far-reaching effects. He writes (Ferguson, 1990: 255) that there is "a kind of logic or intelligibility to what happens when the 'development' apparatus is deployed - a logic that transcends the question of the planners' intentions". Thus, instead of understanding development projects in Lesotho as povertyreduction programmes that incidentally produce an increased bureaucracy, Ferguson suggests that it is more accurate to see them as a machine for expanding state power that happens to take poverty as its starting point.

Fundamentally, Ferguson argues that the development apparatus of technical and bureaucratic fixes to deprivation serves to depoliticise the issue of poverty, leading him to dub it the 'anti-politics machine'. He writes (Ferguson, 1990: 256), "a 'development' project can end up performing extremely sensitive political operations involving the entrenchment and expansion of institutional state power almost invisibly, under cover of a neutral, technical mission to which no one can object". Nonetheless, Ferguson warns against conspiracy thinking, arguing that these effects are the product of the interactions of a network of norms, discourses, and actors. They do not have to be fully intentional to be politically useful, however, or for that usefulness to contribute to the repetition of 'failed' approaches over and over again.

Looking at the Narmada pipeline project and the restructuring of state water governance institutions that has accompanied it, we can see that one instrument-effect has been an increase in the power of a select number of state-level officials (namely the Chief Minister, cabinet, and the appointed heads of various agencies and parastatals) who control the allocation of the water itself as well as contracts for infrastructure O\&M. Although responsibility for drinking water provision has been formally devolved to municipal and village governance bodies in accordance with 1993 amendments to the national constitution, the increasing reliance on centralised infrastructure for water supply effectively undercuts that mandate. Investment in the SSP also effectively reduces the availability of funds for other approaches: Roy (1999) notes that $85 \%$ of the state's irrigation budget was allocated to the SSP, while for drinking and industrial water, GIDB (2009) envisions an outlay of roughly Rs. 60 billion (USD 0.93 
billion) over ten years, as opposed to Rs. 5 billion (USD77.5 million) for conservation and groundwater recharge. In addition to undercutting the autonomy of lower levels of government, the Narmada pipeline project serves to reduce the independence of Gujarat's minority regions: water availability in North Gujarat, Kutch, and Saurashtra is ostensibly no longer determined by local resources but by the state's willingness to deliver water to them. The branching structure of the grid means that water use by upstream (centrally-located) farmers and industrial areas can and does impinge upon water supply for the more marginal regions used to justify the project. Without explicit protections for the most vulnerable - landless people, slum-dwellers, and Muslim and low-caste people who face discrimination - increasing water supply overall disproportionately benefits more powerful sectors of society. The pipeline grid has also facilitated the establishment of industrial parks and special economic zones, often against the wishes of local residents, favouring corporations through both the provision of water and the allocation of BOT contracts (Shah, 2013; Datta, 2015).

Although the disproportionate benefits to certain sectors of society were not necessarily intentionally planned, they nonetheless reflect a context which includes more deliberate efforts to optimise government intervention in the service of industry and GDP growth, to cultivate popular identification with and support for Mr. Modi and the BJP, and to promote a vision of Gujarat that centres south/central Gujarati Hindus and Jains above others. The following section discusses how official knowledge - and the lack thereof - facilitates this gap between the planners' expressed intentions and the impacts on the ground.

\section{Knowledge and ambiguity}

Ferguson (1990) describes how the failed projects he studied in Lesotho were justified by a particular distorted image of the country that is repeated in the reports of international financial institutions and NGOs, and which he calls the fantasy of the less-developed country. Development planners, he argues, describe their project areas as 'primitive', isolated economies whose problems are contained by national boundaries and solvable by intervention at the level of the nation-state. This ubiquitous problem description is not based on the reality of the situation - Lesotho, for example, was deeply embedded in a regional industrial economy - but rather by the discursive norms of a development apparatus that has blueprints for addressing such situations.

In Gujarat, the guiding fantasy is of unjust hydrological imbalance, with 'wasted' water on one side and naturalised water scarcity on the other. While this fantasy is long-standing, it has gained renewed strength in recent years though the GIDB's mandate to envision and promote infrastructure projects. The fear of waste is taken to its logical extreme in the planned Kalpasar project, which aims to prevent any river runoff. Mehta (2001) notes that the narrative of declining rainfall commonly used to explain water scarcity and justify the Narmada project does not reflect the hydrological record. Rather, anthropogenic changes to the environment (namely, de-vegetation and overexploitation of groundwater) have reduced the reserves available in bad years, while a move toward industrialisation and irrigated crops has increased the cost of drought. She argues that this discursive naturalisation of scarcity is reflective of the tendency for narratives that support popular or powerful positions to spread, regardless of their veracity.

The disconnect between popular representations and hydrological data in terms of Kutch's rainfall record is but one example of the ways in which knowledge about the Sardar Sarovar and pipeline projects is contested and malleable. As mentioned above, tentative estimates of average water flow have been taken to represent fixed quantities, and the apparent knowability of water flows has coincided with neo-Malthusian fears of scarcity to justify the (over)allocation of every last drop. Writing about the project is sprinkled with precise numbers, from the height of the dam to the number of villages served and the length of pipe laid, creating an illusion of knowability and authority. In reality, however, flow meters are either not installed or not functional (Hirway and Goswami, 2008). 
In the absence of concrete data on water flow and even on construction progress, overburdened functionaries report crude estimates as fact, leading to official aggregated numbers that have only the flimsiest basis (Aandahl, 2010). It should be noted that the inaccuracy of these numbers is not necessarily born of malice: Gujarat suffers from a shortage of qualified bureaucrats at the district and local levels, and variable water flows simply do not lend themselves well to precise measurement (Anand, 2015). Just as the Narmada pipeline project is justified and made legible through the creation of apparently concrete facts and figures, ignorance and ambiguity are also strategically deployed. ${ }^{9}$ This is not unique to this project; indeed, Coelho (2004: 434) observes of Chennai's municipal water grid that it:

represented a myth of order, produced by silences, euphemisms and half-truths which permitted and regularised the unofficial arrangements through which lower-level bureaucrats, local politicians and the public together devised solutions to the exigencies of daily life. The myths were ritually enacted through public excavations of illegal connections through which engineers policed and protected the integrity of the grid, despite common knowledge of the ubiquitous underground compromises.

Anand (2015: 309) writes that "[i]gnorance (...) is not so much a lack of knowledge as it is a form of not knowing that, like knowledge, participates in the production of meanings, materials, persons and institutions". For example, the official ignorance of water distribution networks within villages and municipalities - which are placed outside the jurisdiction of the Narmada pipeline project - helps maintain the narrative that water insecurity is primarily an issue of regional physical disparities rather than one of social inequality. Similarly, the impossibility of accurately monitoring water consumption from the Narmada grid facilitates a policy of arbitrary allocation of water in response to crises and perceived shortages. We have seen earlier how illicit water pumping by upstream farmers is ignored and tacitly condoned - until a crisis makes it politically necessary to be seen to take action against it. Official ignorance and ambiguity create space in which the fantasy which justifies the project can continue to be asserted even as it contrasts with experiences of the project in everyday life.

Ignorance of this sort is not simply a feature of neglectful or corrupt governance, but is embedded in the choice of particular infrastructure systems over others. In this case, the choice to centralise drinking water distribution and render the entire system easily legible (Scott, 1998) has also flattened regional differences and made it harder to isolate and address water issues in a particular city or district. Indeed, by making it (relatively) easier to add more water to the system than to identify how much water is going to any particular endpoint, the design of the Narmada pipeline predisposes decision-makers toward supply-side rather than demand-side solutions and contributes to a continual increase in the state's water consumption. Similarly, the decision to route water through areas of high demand in an open canal - rather than take whatever steps necessary to enhance local sources, or to reduce consumption - suggests that other priorities took precedence over ensuring water security for the farthest reaches of the state. These decisions, while presented as technical or obvious, are in fact political choices shaped by values and assumptions about the common good.

At the same time, where Ferguson's analysis of the 'anti-politics machine' in Lesotho focused largely on the way the technical nature of development projects depoliticised poverty and provided cover for the expansion of state power, the Narmada pipeline project evidences the important role the spectacle of development projects plays in maintaining state control over populations. Manji (2015: 216) also uses the idea of development as spectacle in her work on highway construction in Kenya, where she argues that "infrastructural capitalism" is serving to prop up political authority as "the heavy lifting

\footnotetext{
9 Readers may also be interested in Sud's (2009) description of how government memos employ silence and indirect references to avoid informing the developers of a Kutch cement factory of relevant environmental regulations that could delay or shut down the project.
} 
equipment [seem] to embody the virility and hard work being done by the state on behalf of its spectator-citizens", even as those who live in the way of the proposed highways are actively dispossessed. Similarly, the promotion of the Narmada pipeline has created an image of massive investment in high-tech water provision that could be marketed both to a domestic audience and international investors, which residents are called to witness and even participate in through the creation of the Statue of Unity, the use of the dam-side recreation area, and grand public celebrations as each new branch of the pipeline is inaugurated. This pageantry is not ideologically neutral; Mehta (2010; 509) notes the "compulsory nativism" of pro-SSP rallies, and Desai and Roy (2016) report that working-class Hindu Gujaratis often cite visible infrastructure when explaining their support for the BJP.

\section{CONCLUSIONS}

This paper has outlined the evolution of the Sardar Sarovar Canal Based Drinking Water Supply Project within the Gujarat model of development. We have seen how efforts to consolidate and make legible the state's drinking water apparatus have allowed water to be easily redirected to politically favoured regions and projects by simultaneously facilitating such transfers on a technical level and concentrating decision-making power within a relatively small elite. Using Ferguson's image of the anti-politics machine, we can understand these instrument-effects as the result of a development discourse and approach that ignores the socio-political dimensions of water poverty and insecurity by presenting technical solutions to problems defined in hydrological terms. While this approach is situated within a longer history of hydrocratic nation-building in India, understanding Gujarat as a developmental state in which state power is leveraged in a coordinated way to promote GDP-enhancing sectors of the economy - helps explain the particular appeal of the Narmada pipeline project as a solution. We have also seen how this is in line with trends that have emerged under the 'Gujarat model of development': the emphasis on infrastructure construction, the centralization of power, and the skilful use of narrative and spectacle as a mode of governance.

I have no wish to downplay the benefits that the SSP and Narmada Pipeline Project have brought to urban and rural residents of Gujarat. Nonetheless, increased water from the Narmada has also been accompanied by a decrease in care for other sources, increased consumption by industry and industrial agriculture, and ongoing elite capture of resources. Although it is impossible to know precisely what the water situation would have been had the Narmada Project not been constructed, it is clear that such a supply-side solution has not addressed the root causes of scarcity and cannot be a permanent fix in a context where demand is continuing to grow, encouraged by state development priorities.

As in many developmental states, the technocratic approach to development adopted by Gujarat presumes a singular common good, ignoring existing inequalities and potentially divergent interests (Wee and Jayasuriya, 2002; Ooi, 2005). Consciously or not, the construction of water infrastructure and water governance structures in contemporary Gujarat reproduces exclusions and power imbalances that mirror the ongoing rhetorical construction of Gujarati identity as culturally tied to the south-central region, Hindu, and aspiring to or engaged in Western-style conspicuous consumption (Desai, 2011). Just as Ferguson (1990) notes that failed development projects do not fundamentally challenge the politicaldiscursive 'machine' that enacted them, reports of the Narmada pipeline grid's limitations and failures continue to feed into the same narratives used initially to justify it, setting up the GoG to argue for the necessity of new mega-infrastructure projects, as we see with the Kalpasar project.

\section{ACKNOWLEDGEMENTS}

The author wishes to thank their doctoral committee, Madhav Badami (Chair), Lisa Bornstein, Govind Gopakumar, and Gonzalo Lizarralde, as well as Darshini Mahadevia and the members of the Centre for Urban Equity at CEPT, and the members of the Centre for Public Policy at IIM - Bangalore, for their 
guidance and hospitality. The author is also grateful to three anonymous reviewers, whose comments have helped strengthen the article. The research discussed in this article was part of a dissertation project generously supported by a Vanier Canada Graduate Scholarship and a Fulbright-Nehru Student Research Scholarship.

\section{REFERENCES}

Aandahl, G. 2010. Technocratic dreams and troublesome beneficiaries: The Sardar Sarovar (Narmada) Project in Gujarat. PhD thesis. University of Oslo, Oslo, Norway.

Anand, N. 2015. Leaky states: Water audits, ignorance, and the politics of infrastructure. Public Culture 27(2): 305330.

Anderson, B. and McFarlane, C. 2011. Assemblage and geography. Area 43(2): 124-127.

ADB (Asian Development Bank). 2004. Gujarat public sector resource management program. Project completion report (Loan 1506-IND). Delhi: Asian Development Bank.

ADB. 2008. Gujarat earthquake rehabilitation and reconstruction project. Project completion report 35068. Delhi: Asian Development Bank.

Bagla, P. 2014. India plans the grandest of canal networks. Science magazine 11 July 2014, p. 128.

Bakker, K. 2010. Privatizing water: Governance failure and the world's urban water crisis. Ithaca, NY: Cornell University Press.

Baviskar, A. 1999. In the belly of the river: Tribal conflicts over development in the Narmada Valley. New Delhi: Oxford University Press.

Biswas-Tortajada, A. 2014. The Gujarat state-wide water supply grid: A step towards water security. International Journal of Water Resources Development 30(1): 78-90.

Bobbio, T. 2012. Making Gujarat vibrant: Hindutva, development and the rise of subnationalism in India. Third World Quarterly 33(4): 657-672.

Census of India. 2011. Households by main source of drinking water and location: Gujarat.

Coelho, K. 2004. Of engineers, rationalities, and rule: An ethnography of neoliberal reform in an urban water utility in South India. PhD thesis. University of Arizona, Tucson, USA.

Comptroller and Auditor General of India. 2006. Audit report (commercial), Gujarat, for the year 2005-2006.

Cullet, P. (Ed). 2007. The Sardar Sarovar Dam project: Selected documents. Aldershot, UK: Ashgate Publishing.

Datta, A. 2015. New urban utopias of postcolonial India: 'Entrepreneurial urbanization' in Dholera smart city, Gujarat. Dialogues in Human Geography 5(1): 3-22.

Dave, K. 2013. Water authority defunct in Gujarat. Times of India, 12 April 2013.

Dave, K. 2016. Gujarat needs an effective water regulatory authority: Water supply minister Vijay Rupani. Times of India, 24 April 2016.

Desai, M. and Roy, I. 2016. Development discourse and popular articulations in urban Gujarat. Critical Asian Studies 48(1): 1-26.

Desai, R. 2011. Gujarat's Hindutva of capitalist development. South Asia: Journal of South Asian Studies 34(3): 35481.

Desai, R. 2012. Governing the urban poor: Riverfront development, slum resettlement and the politics of inclusion in Ahmedabad. Economic and Political Weekly 47(2): 49-56.

Dholakia, A. and Dholakia, R. 2015. Gujarat. In Panagariya, A. and Rao, M.G. (Eds), The making of miracles in Indian states: Andhra Pradesh, Bihar, and Gujarat, pp. 226-323. Oxford, UK: Oxford University Press.

D'Souza, D. 2002. The Narmada dammed: An inquiry into the politics of development. New Delhi: Penguin Books India.

Drèze, J.; Samson, M. and Singh, S. 1997. Dam and the nation: Displacement and resettlement in the Narmada Valley. Delhi: Oxford University Press. 
Dwivedi, R. 1999. Displacement, risks and resistance: Local perceptions and actions in the Sardar Sarovar. Development and Change 30(1): 43-78.

Dwivedi, R. 2006. Conflict and collective action: The Sardar Sarovar Project in India. New Delhi: Routledge.

The Economist. 2015. The Gujarat model. www.economist.com/news/finance-and-economics/21638147-howmodi-nomics-was-forged-one-indias-most-business-friendly-states (accessed on 11 May 2016)

Express News Service. 2012. Modi hands portfolios to all 16 ministers, keeps 9 with himself. The Indian Express. 30 December 2012.

Ferguson, J. 1990. The anti-politics machine: 'Development', depoliticization, and bureaucratic power in Lesotho. Cambridge, UK: Cambridge University Press.

Ferguson, G. and A. Sinnott. 1969. An organizational plan for a comprehensive study of the water resources of the Narmada River basin, India. US Geological Survey.

Fisher, W. (Ed). 1995. Towards sustainable development: Struggling over India's Narmada River. New York: M.E. Sharpe.

GIDB (Gujarat Infrastructure Development Board). 2009. Blueprint for infrastructure in Gujarat (BIG 2020). Gandhinagar: GIDB.

GSDWICL (Gujarat State Drinking Water Infrastructure Co. Ltd.). 2000. Gujarat jal-disha 2010: A vision of a healthy and equitable future with drinking water, hygiene and sanitation for all. Gandhinagar: Gujarat State Drinking Water Infrastructure Co Ltd.

Gupta, R.K. 2001. River basin management: A case study of Narmada valley development with special reference to the Sardar Sarovar Project in Gujarat, India. International Journal of Water Resources Development 17(1): 5578.

Gupta, R.K. 2002. Water and energy linkages for groundwater exploitation: A case study of Gujarat state, India. Water Resources Development 18(1): 25-45.

Hardiman, D. 1998. Well irrigation in Gujarat: Systems of use, hierarchies of control. Economic and Political Weekly 33(25): 1533-44.

The Hindu. 2015. KTR launches water grid project works. The Hindu. 21 September 2015.

Hirway, I. 2000. Dynamics of development in Gujarat: Some issues. Economic \& Political Weekly 35(35-6): 310620.

Hirway, I. 2005. Ensuring drinking water to all: A study in Gujarat. Paper presented at the 4th IWMI-TATA Annual Partners Research Meeting, Anand, India, 24 February 2005.

Hirway, I. and Goswami, S. 2008. Functioning of the drinking water component of the Narmada Pipeline Project in Gujarat. Economic and Political Weekly 43(9): 51-59.

Ibrahim, F. 2007. Capitalism, multiculturalism and tolerance: A perspective on 'Vibrant Gujarat'. Economic and Political Weekly 42(34): 3446-9.

The Indian Express. 2014. Incident an outcome of her anti-Gujarat activities. The Indian Express, 13 August 2014.

Jain, L.C. 2001. Dam vs. drinking water: Exploring the Narmada judgement. Delhi: Parisar.

Jaffrelot, C. 2008. Gujarat: The meaning of Modi's victory. Economic \& Political Weekly 43(15): 12-17.

Jaffrelot, C. 2015a. The Modi-centric BJP 2014 election campaign: New techniques and old tactics. Contemporary South Asia 23(2): 151-166.

Jaffrelot, C. 2015b. What 'Gujarat Model'? - Growth without development - and with socio-political polarisation. South Asia. Journal of South Asian Studies 38(4): 820-838.

Jha, P. 2013. Gujarat water policy may be delayed. DNA India, 29 January 2013.

John, P. 2012. Gujarat's first 29-storey building coming up in capital. Times of India, 2 September 2012.

Johnson, C. 1999. The developmental state: Odyssey of a concept. In Woo-Cumings, M. (Ed), The developmental state, pp. 32-60. Ithaca, NY: Cornell University Press.

Joshi, V. 2000. Cultural context of development. Economic and Political Weekly 35(35/36): 3165-3169.

Kirk, J.A. 2012. India and the World Bank: The politics of aid and influence. Anthem South Asian Studies. Delhi: Anthem Press. 
Klingensmith, D. 2007. 'One valley and a thousand': Dams, nationalism, and development. New York: Oxford University Press.

Kothari, S. 1996. Whose nation? The displaced as victims of development. Economic and Political Weekly 31(24): 1476-1485.

Meehan, K. 2014. Tool-power: Water infrastructure as wellsprings of state power. Geoforum 57(1): 215-24.

Mehta, L. 1997. Water, difference and power: Kutch and the Sardar Sarovar (Narmada) Project. IDS Working Papers 45. Brighton: University of Sussex.

Mehta, L. 2001. The manufacture of popular perceptions of scarcity: Dams and water-related narratives in Gujarat, India. World Development 29(12): 2025-2041.

Mehta, L. 2005. The politics and poetics of water: The naturalisation of scarcity in western India. New Delhi: Orient Blackswan.

Mehta, L. 2011. Experiences and reimaginings of development from a Kutchi village. IDS Bulletin 42(5): 30-35.

Mehta, M.G. 2010. A river of no dissent: Narmada Movement and coercive Gujarati nativism. South Asian History and Culture 1(4): 509-528.

Modi, N. 2012. A great son of Gujarat, a towering leader of India - Tributes to Sardar Patel. Times of India, 31 October 2012, http://blogs.timesofindia.indiatimes.com/narendra-modis-blog/a-great-son-of-gujarat-atowering-leader-of-india-tributes-to-sardar-patel/ (accessed on 10 August 2016)

Mohan, V. and K. Dave. 2014. Narendra Modi gives Gujarat its lifeline: Narmada Dam height to be raised by 17 metres; lakhs will lose their homes, activists say. Times of India, 13 June 2014.

Molle, F.; P. Mollinga and P. Wester. 2009. Hydraulic bureaucracies and the hydraulic mission: Flows of water, flows of power. Water Alternatives 2(3): 328-349.

Morse, B. and T.R. Berger. 1992. Sardar Sarovar: Report of the independent review. Ottawa: Resource Futures International.

Mukherji, A. 2006. Political ecology of groundwater: The contrasting case of water-abundant West Bengal and water-scarce Gujarat, India. Hydrogeology Journal 14(3): 392-406.

NAPM (National Association of People's Movements). 2010. Ordinary people, extraordinary movement. Twenty five years of struggle and quest for alternatives in Narmada Valley. The Movement of India 5(3): 22-25.

Narayan, J. 2001. Large dams and sustainable development: A case-study of the Sardar Sarovar Project, India. International Journal of Water Resources Development 17(4): 601-609.

Ooi, G.L. 2005. The role of the developmental state and interethnic relations in Singapore. Asian Ethnicity 6(2): 109-120.

Parasuraman, S.; H. Upadhyaya and G. Balasubramanian. 2010. Sardar Sarovar Project: The war of attrition. Economic and Political Weekly 45(5): 39-48.

Parmar, V. 2013. In Modi's Gujarat, no Narmada water for Dalits. Times of India, 10 April 2013.

Parmar, V. 2015a. Drones to check water theft in Saurashtra. Times of India, 26 April 2015.

Parmar, V. 2015b. Village gets Narmada water but Dalits don't. Times of India, 14 April 2015.

Patel, A. 2013. Narendra Modi: The one-man cabinet. DNA India, 31 March 2013.

Patel, C.C. 1995. The Sardar Sarovar Project: A victim of time. In Fisher, W. (Ed). 1995. Towards sustainable development: Struggling over India's Narmada River, pp. 71-88. New York: M.E. Sharpe.

Patel, K. 2001. Address by Shri Keshubhai Patel, Chief Minister, Gujarat. 49th National Development Council Meeting, Vigyan Bhavan, New Delhi, 1 September 2001.

Pathak, A. 2001. Modi's meteoric rise. Times of India, 2 October 2001.

Pathak, M. (Ed). 1991. Sardar Sarovar project: A promise for plenty. Delhi: Oxford \& IBH Publishing Co.

Performance Assessment Project. 2016. Urban water and sanitation in Gujarat: Summary report 2009-2016. Ahmedabad: Urban Management Centre.

Pravah. 2009. Collective efforts for self-reliance in drinking water \& sanitation. Annual Report 2008 - 9. Ahmedabad: Pravah. 
PTI (Press Trust of India). 2014. Narendra Modi reviews Gujarat water supply situation, urges focus on Kutch. DNA India, 13 May 2014.

PTI. 2015a. Gujarat CM inaugurates pipeline project in Surendranagar. Business Standard, 5 April 2015.

PTI. 2015b. Guj govt to set up new SRP battalion to boost security. Times of India, 14 September 2015.

Rittel, H.W.J. and Webber, M.M. 1973. Dilemmas in a general theory of planning. Policy Sciences 4(2): 155-169.

Roy, A. 1999. The greater common good. Mumbai: India Book Distributor Ltd.

SSNNL (Sardar Sarovar Narmada Nigam Ltd.) n.d. Domestic Water Supply. www.sardarsarovardam.org/domesticwater-supply.aspx (accessed 26 November 2016)

Scott, J. 1998. Seeing like a state: How certain schemes to improve the human condition have failed. New Haven: Yale University Press.

Shah, R. 2010. Gujarat to double water charges for industry. Times of India, 12 November 2010.

Shah, R. 2012a. Narmada water for Dahej, Bharuch industries. Times of India, 10 February 2012.

Shah, R. 2012b. Govt on war footing to quench Saurashtra with Narmada waters. Times of India, 13 June 2012.

Shah, R. 2013. Demand for scarce Narmada waters for Dholera special investment region. Times of India, 4 January 2013.

Shah, T.; Bhatt, S.; Shah, R.K. and Talati, J. 2008. Groundwater governance through electricity supply management: Assessing an innovative intervention in Gujarat, western India. Agricultural Water Management 95(11): 1233-1242.

Shiva, V. 2002. Water wars: Privatization, pollution and profit. Toronto: Between the Lines.

Simpson, E. 2013. The political biography of an earthquake: Aftermath and amnesia in Gujarat, India. London, UK: Hurst.

Simpson, E. and A. Kapadia. 2010. The idea of Gujarat: History, ethnography and text. New Delhi: Orient Blackswan.

Sinha, A. 2003. Rethinking the developmental state model: Divided leviathan and subnational comparisons in India. Comparative Politics 35(4): 459-476.

SANDRP (South Asia Network on Dams, Rivers and People). 2000. The drought, the state and the people: An experience in Gujarat, 2000. New Delhi: SANDRP.

Sud, N. 2009. The Indian state in a liberalizing landscape. Development and Change 40(4): 645-665.

Swayamprakash, R. 2013. Exportable engineering expertise for 'Development': A story of large dams in post independence India. Water History 6(2): 153-165.

Swyngedouw, E. 1999. Modernity and hybridity: Nature, regeneracionismo, and the production of the Spanish waterscape, 1890-1930. Annals of the Association of American Geographers 89(3): 443-465.

TNN (Times News Network). 2002. Narmada waters diverted to Sabarmati. 28 August 2002.

TNN. 2005. Modi scripts Saraswati 'rebirth'. Times of India, 25 August 2005.

TNN. 2012. Hitachi to build Asia's biggest desalination plant. Times of India, 23 March 2012.

TNN. 2013. Narmada water supply to Vadodara Municipal Corporation waterworks faces hiccups. Times of India, 8 October 2013.

TNN. 2015a. New pipeline scheme for parched Saurashtra. Times of India, 6 April 2015.

TNN. 2015b. Row over water sparks riots. Times of India, 28 February 2015.

Verniers, G. 2015. L'Inde de Modi: Bilan politique de sa première année au pouvoir. PRIAS lecture, Université de Montréal, Montreal, 9 March 2015.

Vibrant Gujarat. 2014. Megaprojects: Avenues for investment in Gujarat. https://www.slideshare.net/vibrant_gujarat/large-project-opportunities-in-gujarat-profile-41341184 (accessed on 24 May 2017)

Vyas, J.N. 2001. Water and energy for development in Gujarat with special focus on the Sardar Sarovar project. International Journal of Water Resources Development 17(1): 37-54.

Vyas, S. 2016. Maharashtra learns from Gujarat to build water grid. The Hindu, 8 June 2016. 
WASMO (Water and Sanitation Management Organisation). 2015. Brochure.

www.wasmo.org/downloads/wasmo brochure 22062015.pdf (accessed on 24 May 2017)

WASMO. 2016. Establishing WASMO. http://wasmo.org/showpage.aspx?contentid=45 (accessed on 19 July 2016)

Wittfogel, K. 1957. Oriental despotism: A comparative study of total power. New Haven: Yale University Press.

Wee, V. and Jayasuriya, K. 2002. New geographies and temporalities of power: Exploring the new fault-lines of Southeast Asia. The Pacific Review 15(4): 475-495.

Wood, J. 1993. India's Narmada River dams: Sardar Sarovar under siege. Asian Survey 33(10): 968-984.

Yagnik, A. and S. Sheth. 2005. The shaping of modern Gujarat: Plurality, Hindutva, and beyond. New Delhi: Penguin Books India.

THIS ARTICLE IS DISTRIBUTED UNDER THE TERMS OF THE CREATIVE COMMONS ATtRIBUTION-NONCOMMERCIAL-SHAREALIKE LICENSE WHICH PERMITS ANY NON COMMERCIAL USE, DISTRIBUTION, AND REPRODUCTION IN ANY MEDIUM, PROVIDED THE ORIGINAL AUTHOR(S) AND SOURCE ARE CREDITED. SEE HTTP://CREATIVECOMMONS.ORG/LICENSES/BY-NC-SA/3.0/LEGALCODE 